\title{
Rising Powers in a Changing Global Order: The Political Economy of Turkey in the Age of BRICs
}

\author{
Ziya Öniş-Mustafa Kutlay
}

\section{Third World Quarterly, Vol. 34, No. 8, 2013, pp. 1409-1426}

\begin{abstract}
The rise of BRICs presents a major challenge to the existing global order. A second category of emerging powers, which may be labeled near-BRICs have also displayed increasing pro-activism in recent years in terms of influencing the regional balance of power politics in addition to their growing presence in international organizations and global affairs. It is in this context that we aim to examine Turkey as a striking example of a "near-BRIC" power, a country that has adapted an increasingly assertive and independent style of foreign policy with aspirations to establish itself as a major regional actor. Using the Turkish experience as a reference point, this paper aims to understand the extent to which near-BRICs possess the economic capacity, sustainable growth performance and soft-power capabilities needed to establish themselves as significant regional and global actors. The recent Turkish experience clearly highlights both the potential and the limits of regional power activism on the part of emerging powers from the "global south."
\end{abstract}

Keywords: Regional powers, hegemonic power shifts, BRICs, democratization, Turkish political economy and foreign policy.

Ziya Öniş is in the Department of International Relations and Political Science, Koç University, Rumelifeneri Yolu, 34450, Sarlyer, Istanbul,Turkey.Email: zonis@ku.edu.tr.

Mustafa Kutlay is in the Department of International Relations and Political Science, Koç University, Rumelifeneri Yolu, 34450,Sartyer, İstanbul,Turkey.Email: mkutlay@ku.edu.tr. 


\section{Introduction: The dynamics of a changing global order}

One of the "great debates" of international politics today revolves around the global shifts taking place within the interstate system. Students of international politics have increasingly engaged in a lively discussion, sparking alternative views on the dynamics, nature, and consequences of a possible transformation from a US-centered system to a multi-polar global order. ${ }^{1}$ Many scholars argue that we have already entered a postAmerican world, ${ }^{2}$ which has crystallized after the global financial crisis triggered by the bankruptcy of Lehman Brothers, one of the world's biggest investment banks, in September $2008 .^{3}$ The strikingly high post-crisis growth performance of the emerging non-western powers, especially the BRIC (Brazil, Russia, India, and China) and nearBRIC countries (Mexico, South Korea, Turkey, Indonesia, and Malaysia), ${ }^{4}$ in comparison to the weak recovery in the US and the deepening crisis in the European Union, have accelerated the "west vs. the rest" debate. ${ }^{5}$

The international system passes through an interregnum period, and as Gramsci has put it, the old order is dying but the new cannot be born. The current phase of transformation from uni-polarity to a multi-polar system is characterized by three simultaneous developments. First, the power diffusion in the international political economy system is not accompanied by a parallel process of reallocation of power. It is quite clear that the US is no longer an example of the "textbook definition of hegemony"; that is, it lacks the ability to shape single-handedly the political and economic governance structures of the interstate system, as it used to be. Yet, the power shift from the US has so far not been 
accompanied by a re-accumulation in the hands of another potential hegemonic actor. The power transition proceeds in a diffused manner, covering a group of challengers. The second striking development, following closely the trend noted above, concerns the increasing tendency towards regionalization in the global political economy. ${ }^{6}$ The globalization wave of the last thirty years has unleashed a new wave of regionalization, which paves the way for the emergence of autonomous regional security orders. ${ }^{7}$ The third development, in this context, involves the rise of new regional powers and "catchup states. ${ }^{, 8}$ Accordingly, the arduous reshuffling of the global order and the uncertainty stemming from the waning hegemonic check and balance mechanisms enable regional powers to assume more autonomy in their domestic and foreign affairs. The complex interaction of these three developments has led to a political economy structure in which regional powers enjoy greater room for autonomy to pursue their own regional agendas and invest in more assertive foreign policy strategies, rather than passively adapting themselves to roles otherwise attributed to them by the great powers. The rise of BRICs and near-BRICs in the regional orders and the international system is a clear illustration of this trend.

In times of global power transitions, an overriding question centers on the underlying capacities of the rising powers to play increasingly ambitious regional and global roles. A related question in this context is whether such countries have the capacity to generate high rates of economic growth on a sustainable basis: To what extent is current proactivism and regional assertiveness sustainable for regional powers, especially when taking into consideration domestic political economy challenges? This article addresses 
these questions by assessing Turkey's credentials to play an assertive regional leadership role, probing into its key political economy fundamentals. We believe that Turkey constitutes a critical case for studying a more general phenomenon - that is, the potential and the limits of emerging power influence in a rapidly shifting global order. We outline the possible risks and challenges pertaining to Turkey's ability to match its rising aspirations with its actual power resources and capabilities. While we recognize the limitations of single-country case studies for the purposes of large-scale generalizations, ${ }^{9}$ we believe that the Turkish experience provides a strong basis for shedding light on the principal theme of this paper. Turkey is clearly an interesting country from a broader comparative perspective, especially when considering its recent economic and political transformation, its long-standing Western orientation and membership of the transatlantic security alliance, as well as its quest to play a more independent regional role in the greater Middle East, without necessarily jeopardizing its traditional alliances.

The article proceeds as follows: The next section provides a brief critical overview on the dynamics of Turkey's rising regional presence in the international system heading towards multi-polarity. The third section concentrates on the underlying political economy fundamentals of Turkey's current foreign policy pro-activism and explores the risks and challenges associated with the on-going systemic transformations. The final part attempts to generate broader insights into the debate concerning the degree and depth of influence that rising or emerging powers are likely to exercise in an era of profound global power shifts. ${ }^{10}$ 


\section{Turkey: A new "benign regional power" in the making?}

Turkish politics during the past decade has been dominated by the right of center, the Justice and Development Party (Adalet ve Kalkınma Partisi, AKP), distinguished by its moderate Islamist heritage. ${ }^{11}$ Over the course of the AKP era, Turkey has struggled increasingly to position itself as a "benign regional power," especially in the Middle East, North Africa and the Balkans. ${ }^{12}$ Turkey's current foreign policy reflects a more multidimensional and regionally oriented outlook in comparison to the strictly westernoriented policies it pursued during the Cold War and the early phase of the post-Cold War era. Turkey now considers itself an "insider" of the Middle East and North Africa region, so much so that Turkish Prime Minister Recep Tayyip Erdoğan even declared the Syrian civil war as "an internal affair of Turkey." 13 In fact, significant segments of the elites as well as the public at large in the Arab Middle East have shown a positive reception of Turkey's relatively assertive and independent foreign policy approach. According to a recent research, 73 per cent believe that "Turkey has become more influential in Middle Eastern politics," and 66 per cent think that "Turkey can be a model

for countries" in the Middle East. ${ }^{14}$ Yet, this positive view is counterbalanced by the fact that this new foreign policy activism is also regarded in some circles, both at home and abroad, as a reflection of the revival of "neo-Ottomanism", which contrasts with the vision of a benign regional power. ${ }^{15}$

Turkey's increasing engagement with the region has naturally attracted the attention of students of Turkish foreign policy. Not surprisingly, explanations about the dynamics of rising pro-activism vary significantly. One group of analysts has developed an identity- 
based explanation, by putting special emphasis on the ideological orientation of the moderately Islamist AKP and has identified Sunni-Islam-driven "civilizational geopolitics" as the constituting foreign policy paradigm. ${ }^{16}$ A second group of scholars, on the other hand, has developed an alternative, interest-based explanation, which underlines the changing security dynamics of the international and regional orders. Accordingly, wars in Afghanistan and Iraq have triggered a power vacuum around Turkey's sphere of interest, and Turkish policy-makers have responded pro-actively to this transformation, especially after the triumphant rise of the conservative AKP in the early 2000s. ${ }^{17}$

We argue that these explanations are not necessarily mutually exclusive. One cannot understand the AKP's active engagement in the greater Middle East without taking its moderate Islamic identity into consideration. However, simply concentrating on the civilizational dimensions of the "new" Turkish foreign policy would miss out on the deeper domestic, regional, and international political economy dynamics at work. Hence, there is a need to combine these different perspectives to provide a coherent and holistic explanation of the more assertive Turkish foreign policy over the last decade, taking into account the interplay of external dynamics and domestic transformations. Along these lines, we offer an analytically eclectic perspective that combines the interactions between agents and structure, rather than relying on mono-causal explanations. ${ }^{18}$

At the systemic level, the hegemonic power transformations have provided a window of opportunity for regional actors to act relatively more independent in comparison to periods when systemic control mechanisms were tight and robust. The declining power of 
the US after the wars in Afghanistan and Iraq, accompanied by the rise of BRICs, has paved the way for a period of structural indeterminism, especially in the greater Middle East, so that regional actors like Turkey have had the opportunity to act in a relatively autonomous manner. A structure-oriented approach, however, is inadequate for explaining Turkey's rising regional pro-activism per se. One has to add the agent-level dynamics into the equation so as not to overlook the details beneath the surface. In this context, Ahmet Davutoğlu, Prime Minister Erdoğan's chief adviser until 2009 and subsequent Minister of Foreign Affairs, played a crucial role in formulating the current parameters of Turkish foreign policy, which in the era before the Arab upheavals involved a pro-active engagement strategy by way of "combining economic interdependence and cultural affinity with no explicit agenda for democracy promotion." ${ }^{19}$ With the onset of the Arab Spring, however, the promotion of democracy has become a central pillar of Turkish foreign policy in the region. The current proactivism in Turkish foreign policy, therefore, increasingly relies on two pillars: economic interdependence, and explicit pro-democracy rhetoric. The Turkish government's grand strategy is to position Turkey as a soft-power driven, "benign" regional player that promotes and utilizes economic interdependence and democratization. Davutoğlu has defined this foreign policy strategy as follows: "In the economic realm, as an emerging economic power, we need to act as businessman... [In the political realm], we would be the staunch supporter of human rights and democracy." 20

Major reforms in the economic and democratization spheres have constituted the basis of the AKP's soft-power driven foreign policy over the course of the last decade. In the 
economic realm, the AKP government has built on the foundations laid during the coalition government in the aftermath of the 2001 economic crisis, whose impact on the Turkish economy had been quite devastating. The Turkish financial system was restructured in the wake of crisis. Public finance was put in order and a suitable environment was created for domestic and foreign investors. ${ }^{21}$ Turkey during this period also benefited from a favorable global liquidity environment and managed to attract significant inflows of long-term foreign direct investment for the first time in its recent economic history. As a result, the Turkish economy and the GDP per capita grew more than threefold at current prices, in addition to a fourfold increase in Turkish foreign trade over the last decade (see Table 1). Parallel developments took place in terms of democratization. Especially during the "golden age" of Europeanization (1999-2006), under the strong influence of the drive towards full membership in the European Union, the AKP government accomplished major democratization reforms. The depth of the reform process is indicated by the fact that two constitutional and nine legislative packages were enacted. ${ }^{22}$ One of the most dramatic changes during this era involved the abandonment of the official state policy of denying the existence of Kurdish identity, which encouraged a peaceful solution to the deep-seated Kurdish problem to appear on the political horizon. ${ }^{23}$ 


\begin{tabular}{|l|c|c|c|c|c|c|c|c|c|c|c|}
\hline \multicolumn{10}{|c|}{ Table 1. Turkey's economic performance over the last decade (2002-2012) } \\
\hline & $\mathbf{2 0 0 2}$ & $\mathbf{2 0 0 3}$ & $\mathbf{2 0 0 4}$ & $\mathbf{2 0 0 5}$ & $\mathbf{2 0 0 6}$ & $\mathbf{2 0 0 7}$ & $\mathbf{2 0 0 8}$ & $\mathbf{2 0 0 9}$ & $\mathbf{2 0 1 0}$ & $\mathbf{2 0 1 1}$ & $\mathbf{2 0 1 2}$ \\
\hline GDP (US \$ billions, c. prices) & 232.7 & 304.6 & 393 & 484 & 529.9 & 655.9 & 742.1 & 617.6 & 735.8 & 772,3 & 794,5 \\
\hline GDP per capita (US \$, c. prices) & 3,403 & 4,393 & 5,595 & 6,801 & 7,351 & 8,984 & 10,745 & 8,95 & 10,067 & 10,469 & 10,609 \\
\hline Real GDP growth (\%) & 6.2 & 5.3 & 9.4 & 8.4 & 6.9 & 4.6 & 0.7 & -4.7 & 9 & 8.5 & 2.2 \\
\hline Investment (\% of GDP) & 17.1 & 17.4 & 20.7 & 21.4 & 22.6 & 21.8 & 20.2 & 17.2 & 18.9 & 23.8 & 20.6 \\
\hline Savings (\% of GDP) & 18.3 & 15.1 & 15.6 & 15.7 & 16.2 & 15.8 & 6.8 & 13.1 & 12.6 & 13.8 & 14.7 \\
\hline Imports (US \$ billions) & 51.5 & 69.3 & 97.5 & 116.8 & 139.6 & 170.1 & 201 & 140.9 & 185.5 & 240.8 & 236.5 \\
\hline Exports (US \$ billions) & 36.1 & 47.3 & 63.2 & 73.5 & 85.5 & 107.3 & 132 & 102.1 & 113.9 & 135 & 152.5 \\
\hline CAB (\% of GDP) & -0.27 & -2.47 & -3.67 & -4.57 & -6.02 & -5.75 & -5.25 & -2.24 & -6.49 & -9.7 & -6 \\
\hline FDI (US \$ billions) & 1.08 & 1.75 & 2.79 & 8.97 & 19.26 & 19.94 & 16.96 & 6.86 & 7.81 & 16 & 12.6 \\
\hline Fiscal balance (\% of GDP) & -11.5 & -8.8 & -5.22 & -1.3 & -0.61 & -1.62 & -1.8 & -5.5 & -3.6 & -1.4 & -2 \\
\hline Public debt (\% of GDP) & 74 & 67.7 & 59.6 & 52.7 & 46.5 & 40 & 40 & 46.1 & 42.4 & 39.2 & 36.1 \\
\hline Unemployment (\%) & 10.3 & 10.5 & 10.3 & 10.3 & 9.9 & 9.9 & 11 & 14 & 11.9 & 9.8 & 10.1 \\
\hline Source: Turkish Statistical Institute Database, IMF World Economic Outlook Database & & \\
\hline
\end{tabular}

Turkey's economic success in the aftermath of the 2001 crisis clearly laid the foundations for a more assertive foreign policy and Ankara's rise as an increasingly influential regional power. Indeed, there appears to be a similar pattern in this realm to other BRIC countries, such as China and Brazil. During the period in question, we observe the rise of Turkey as a "trading state," 24 with economic linkages gradually constituting bridges of mutual interaction with the key countries in the region. Turkey's trade volume nearly quadrupled over the last decade, and its economic relations with the neighboring countries intensified in parallel to global economic power shifts. For example, in 2002, Asia received only 15 per cent of Turkey's total exports, but by 2012 this ratio had grown astronomically, to 35.3 per cent. Similarly, the Middle East has become a promising destination with increasing importance in terms of market diversification. Between 2002 and 2012, Turkey's exports to the region increased from just 3.4 to 42.4 billion US dollars. On the other hand, the share of the European Union in Turkey's total exports, 
which had been around 56 per cent in 2002, slumped to an unprecedented low level of 38 per cent in $2012 .^{25}$

The onset of the Arab upheavals clearly presented a major challenge to this benign scenario based primarily on the notion of mutual economic interests. Turkish foreign policy has experienced a process of adaptation in the highly uncertain environment of the Arab Spring with democratization and concern with human rights emerging as fundamental ingredients of Turkey's approach, which targeted brutal authoritarian regimes such as the Qaddafi regime in Libya and the Al-Assad regime in Syria on the basis of a combination of economic interests and democratic concerns. Turkey was confronted with a major and inevitable dilemma, which was clearly absent in the preSpring era when the focus of policy was single-mindedly on mutual economic interdependence with no visible concern for regime transformation. ${ }^{26}$

In the medium term, the process of political change in the Arab Middle East has created a window of opportunity for Turkey because Ankara has the potential to contribute to the process of economic and political restructuring in the region, as well as the potential to benefit from this process. One also needs to recognize, however, that the on-going Arab revolutions have entailed costs for Turkey, in the short-run notably in Syria and Libya, not only in the economic realm, but also in terms of a deterioration of relations with key neighboring states. The Syrian crisis, in particular, constituted an important test case for Turkey's capacity to perform the role of a benign regional power. Arguably, Turkey's ability to play a constructive role in resolving the Syrian crisis has been constrained and 
undermined due to its excessive involvement in Syrian domestic politics. In retrospect, the Syrian crisis also highlights the limits of emerging powers like Turkey to exert a major impact in terms of resolving major regional crises, through unilateral action, in a context where global and other regional powers are heavily involved.

\section{The political economy of Turkey's quest for regional power influence}

The performance of the Turkish economy over the last decade has been rather impressive, judged by its own historical standards and the performance of the region as a whole. Having argued that soft-power driven regional power strategy has become the central pillar for Turkey's quest to undertake a more active regional role and to present itself as a model for the wider Middle East, we probe more deeply into the underlying dynamics of Turkey's recent political economy success. A key question to consider here is whether Turkey's capabilities actually match the expectations of the AKP elites. Since Turkey's aim is to position itself as a "benign regional power" relying on the pillars of economic penetration and democratic deepening, the robustness of these building blocks needs to be investigated in further detail. We argue that the sustainability of Turkey's economic success and democratic credentials is by no means self-evident and that there are significant political economy challenges ahead. Indeed, Turkey faces two proximate and two structural challenges in its quest for regional power influence, which tends to place the country on a kind of knife-edge equilibrium. 


\section{Turkey's economic challenges: Two Achilles heels}

There are two interdependent proximate challenges creating imminent fragilities for Turkish political economy, namely chronic current account deficit and extensive energy dependence. The current account deficit reached an alarmingly high level of almost 10 per cent of its GDP in 2011, making Turkey potentially defenseless against sudden stops of capital inflows. The root causes of Turkey's current account deficit are deep-seated. Savings rates, historically quite low, have followed a negative downward slope over the last decade, and current savings rates in Turkey (about 14 per cent) are exceptionally low, especially in comparison to BRIC countries (see Table 2). This ratio has been around 19 per cent over the last decade, which is well below the average of emerging and developing markets—-that is, 27.5 per cent. ${ }^{27}$

\begin{tabular}{|l|c|c|c|c|c|}
\hline \multicolumn{7}{|c|}{ Table 2. Turkey vs. BRICs, basic indicators (2011) } \\
\hline & Brazil & China & India & Russia & Turkey \\
\hline GDP (billion US \$) & 2,493 & 7,298 & 1,827 & 1,850 & 774 \\
\hline GDP per capita (US \$, ppp) & 11,769 & 8,386 & 3,662 & 16,735 & 14,392 \\
\hline Total investment (\% of GDP) & 20.6 & 48.6 & 35 & 23.2 & 23.8 \\
\hline Gross national savings (\% of GDP) & 18.5 & 51.3 & 31.6 & 28.5 & 13.8 \\
\hline Value of oil imports (billion US \$) & 37.49 & 235.75 & 141.75 & 0 & 54.11 \\
\hline Value of oil exports (billion US \$) & 5.17 & 25.12 & 56.32 & 277.52 & 6.53 \\
\hline Unemployment rate (\%) & 6 & 4.1 & 9.8 & 6.5 & 9.8 \\
\hline Population (millions) & 194.9 & $1,347.3$ & $1,206.9$ & 142.4 & 74.7 \\
\hline Government gross debt (\% of GDP) & 64.9 & 25.8 & 67 & 11.7 & 39.2 \\
\hline Current account balance (\% of GDP) & -2.1 & 2.7 & -3.4 & 5.3 & -9.9 \\
\hline Source: IMF World Economic Outlook Database & & & & \\
\hline
\end{tabular}

Since savings fall short of investments, Turkey needs foreign capital to finance its current account deficit. This Achilles heel places certain structural limits on Turkey's economic growth, primarily driven by inflows of foreign capital. Overdependence on foreign 
capital, on the other hand, increases the vulnerability of the country, because it makes the economy increasingly sensitive to external shocks, ${ }^{28}$ especially at a time when serious economic recession continues to persist at the very center of the global system.

Historically informed analysis of the Turkish economy highlights quite conclusively that economic crises follow a similar sequencing: high economic growth exacerbates the current account deficit, and sudden stop of capital inflows by any reason triggers economic crises. ${ }^{29}$ The crisis-growth-current account deficit-crisis circle still constitutes as an inherent fragility of the Turkish economy, despite the improvements in budgetary performance and a relatively tightly regulated banking and financial system. ${ }^{30}$ The second and interrelated proximate challenge for the economy is centered on Turkey's overdependence on energy. In 2011, Turkey imported more than 90 per cent of its total liquid fuel consumption, comprising an energy import bill of approximately 55 billion US dollars. Moreover, according to a recent International Energy Agency report, Turkey’s imports are expected to double over the next decade. ${ }^{31}$

High degrees of energy dependence and low savings rates, combined with low technological capacity, mutually constitute the major structural root causes of Turkey's chronic current account deficit. These constraints, in turn, significantly restrict Turkey's foreign policy pro-activism since they lead to a kind of asymmetric power relationship with other key actors involved in the region, which could be classified as "coercive regional powers." For example, asymmetric balance of power relationship, which is clearly evident in the case of Turkish-Russian and Turkish-Iranian relations, places important restrictions on Turkey in terms of developing independent strategies in key 
regional conflicts and exert an even more powerful influence in the direction of democratization and regime transformation in the region. Low technological capacity, on the other hand, curtails Turkey's soft-power credentials by raising questions about its capacity as a "trading state." The composition of the Turkish foreign trade sends mixed signals in this regard. While the share of goods based on natural resources and low technology in Turkey's total exports was 63 per cent in 2002, this ratio declined to 56 per cent in 2010. Additionally, the share of mid-tech manufactured goods rose to 44 per cent, a number that in 2002 was only 37 per cent. ${ }^{32}$ However, the share of high-tech goods in Turkey's total exports declined to almost 2 per cent, which is an exceptionally and alarmingly low ratio in comparison to BRIC and OECD averages (see Table 3).

\begin{tabular}{|l|c|c|c|c|c|c|c|c|c|c|c|}
\hline \multicolumn{10}{|c|}{ Table 3. Exports with a high technology content (\% of manufactured goods) } \\
\hline & $\mathbf{2 0 0 0}$ & $\mathbf{2 0 0 1}$ & $\mathbf{2 0 0 2}$ & $\mathbf{2 0 0 3}$ & $\mathbf{2 0 0 4}$ & $\mathbf{2 0 0 5}$ & $\mathbf{2 0 0 6}$ & $\mathbf{2 0 0 7}$ & $\mathbf{2 0 0 8}$ & $\mathbf{2 0 0 9}$ & $\mathbf{2 0 1 0}$ \\
\hline OECD members & 24.40 & 23.20 & 21.90 & 20.65 & 20.33 & 20.40 & 20.48 & 16.88 & 16.26 & 17.12 & 16.20 \\
\hline Brazil & 18.73 & 19.25 & 16.52 & 11.96 & 11.59 & 12.84 & 12.08 & 11.87 & 11.65 & 13.20 & 11.21 \\
\hline China & 18.98 & 20.96 & 23.67 & 27.38 & 30.06 & 30.84 & 30.51 & 26.66 & 25.57 & 27.53 & 27.51 \\
\hline India & 6.26 & 6.97 & 6.24 & 5.95 & 6.00 & 5.80 & 6.07 & 6.40 & 6.78 & 9.09 & 7.18 \\
\hline Russia & 16.07 & 14.04 & 19.16 & 18.98 & 12.92 & 8.44 & 7.78 & 6.88 & 6.47 & 9.23 & 8.85 \\
\hline Turkey & 4.83 & 3.87 & 1.79 & 1.93 & 1.90 & 1.47 & 1.85 & 1.89 & 1.62 & 1.74 & 1.93 \\
\hline Source: World Bank, Development Indicators Database \\
\hline
\end{tabular}

\section{Long-term structural challenges: The two traps argument}

The proximate challenges constitute just one side of the coin. Turkey stands at the crossroads of two traps that have great potential to impede the sustainability of Turkey's regional power credentials. The first structural political economy constraint concerns the middle-income trap and the challenge of institutional transformation. The middle-income trap refers to the slow-down tendency for fast-developing countries after their GDP per capita has reached a certain threshold. ${ }^{33}$ Research on the middle-income trap reveals that 
for most of the countries it becomes an arduous task to improve their GDP per capita from middle to high income levels. The World Bank's research estimates that of the 101 middle-income countries in 1960 only 13 reached high-income level status by $2008 .^{34}$ The overwhelming majority was unable to accomplish the jump and became stuck in the middle. As the economy moves from labor-intensive, low-cost exports toward capitalintensive production, labor is re-allocated from agriculture to manufacturing sectors. This leads to the slow-down of economic growth, because productivity growth from sectoral re-allocation and technology import disappears. Countries that reach middle-income level, therefore, must develop more sophisticated strategies and associated institutions to overcome this trap.

Turkey's GDP per capita, which is around 10,500 US dollars at current prices, suggests that the Turkish political economy indeed approaches a crossroad in terms of a possible middle-income trap. ${ }^{35}$ The broad empirical evidence on this issue indicates that economic and political institutions need to be transformed into "inclusive" ones to promote longterm economic growth. ${ }^{36}$ The institutionalist literature proposes that the most effective way to get out of the middle-income trap and to sustain long-term growth is to improve the institutional structure regarding education policies, the justice system, and the infrastructure in an inclusive way, so as to reap the maximum potential of human capital in the country. Acemoğlu and Robinson succinctly put the issue as follows: ${ }^{37}$

Inclusive economic institutions that enforce property rights, create a level playing field, and encourage investments in new technologies and skills are more conducive to economic growth than extractive economic institutions that are structured to extract resources from the many by the few and that fail to protect 
property rights or provide incentives for economic activity. Inclusive economic institutions are in turn supported by, and support, inclusive political institutions, that is, those that distribute political power widely in a pluralistic manner... Extractive economic institutions are synergistically linked to extractive political institutions.

The long-term sustainability of Turkey's development performance is closely linked to the development of inclusive political and economic institutions. The existing institutional structures in Turkey, however, resemble a semi-extractive country in Acemoğlu and Robinson's terminology. Turkey is lagging far behind in the human development index, an oft-cited proxy indicator for measuring the countries' development level. Turkey ranks $92^{\text {nd }}$ among 187 countries; it is barely in a better position than China and India and lags behind Brazil and Russia. ${ }^{38}$ The figures regarding the competitiveness, institutional quality, corruption perception, and literacy indices also refer to a similar mediocre performance (see Table 4), especially for a country that positions itself as a democratic variant of those included in the BRIC or near-BRIC category.

\begin{tabular}{|l|c|c|c|c|c|}
\hline \multicolumn{7}{|c|}{ Table 4. Turkey's institutional development performance (2011) } \\
\hline & Turkey & Brazil & Russia & India & China \\
\hline Indicator/\# of country & Ranking & Ranking & Ranking & Ranking & Ranking \\
\hline Corruption perception index (182) & 61 & 73 & 143 & 95 & 75 \\
\hline Democracy index (167) & 88 & 42 & 102 & 35 & 138 \\
\hline Competitiveness index (142) & 59 & 53 & 66 & 56 & 26 \\
\hline Human development index (187) & 92 & 84 & 66 & 134 & 101 \\
\hline GDP per capita (183) & 64 & 58 & 55 & 141 & 91 \\
\hline Literacy (205) & 132 & 126 & 15 & 177 & 106 \\
\hline GDP (210) & 17 & 7 & 11 & 9 & 2 \\
\hline $\begin{array}{l}\text { Sources: Transparency International, Economist Intelligence Unit, World Economic Forum, UNDP, World } \\
\text { Bank, UNESCO Databases }\end{array}$
\end{tabular}


The discussion about institutional quality leads us to the second important structural challenge for Turkey in positioning itself as a "benign regional power"-namely, the transition from a "procedural" to "substantive" democracy. An essential part of Turkey's regional power capacity stems from its institutionalized democracy and pluralistic sociopolitical order, as a secular country composed of an overwhelmingly Muslim population. Civil-military relations in Turkey have undergone a significant transformation over the course of the last decade, and the improvement of human rights standards is by no means negligible. The widespread democratization reforms during the intense Europeanization period between 1999 and 2006, the democratic opening that has addressed Turkey's deep-seated Kurdish question, and the constitutional reform attempts are all important indicators of democratization. ${ }^{39}$ Furthermore, the éminence grise of Turkish politics-the military—does no longer hold absolute power in its hands to shape the political direction of the country. All these developments are clearly necessary, but not sufficient steps towards the consolidation of substantive democracy in Turkey. The central question currently revolves around the nature and ultimate result of this power shift: how would the elected authorities use the power accumulated in their hands?

Democratization theories point towards the establishment of robust checks and balance mechanisms as a crucial component in distributing political power and consolidating democratic governance as "the only game in the town." ${ }^{, 0}$ In this context, similar to the middle-income trap argument, Turkey stands at a critical juncture as well. A central problem faced by the democratization process in Turkey in its current stage is the very absence of adequate checks and balance mechanisms to curb excessive concentration of 
power at the very center of the political system. This Gordian knot constitutes the essence of the present debate regarding Turkish democracy, because democratization of the civil sphere still needs to be strengthened, despite the successful transformation of civilmilitary relations in favor of civilian authority. The current situation puts Turkey into a grey zone,${ }^{41}$ swinging between electoral democracy and selective democrats. ${ }^{42}$ Serious charges have been leveled against a narrow, majoritarian understanding of democracy emerging in Turkey towards the end of the AKP decade, especially when judged in terms of the virtual absence of judiciary autonomy, the weak tolerance for opposition and press freedom, as well as lack of genuine respect for political pluralism. ${ }^{43}$ Indeed, the popular protests against AKP in May-June 2013 and the use of excessive force to counter these protests, which attracted widespread international media attention, seem to reflect both the entrenchment and growing reaction against illiberal democracy in Turkey. ${ }^{44}$

Improvements in the quality of democratic consolidation and human rights performance are significant objectives in their own rights and should not be conceived in instrumental terms, serving only as an intermediate step in the process of achieving other objectives. This observation, however, should not detract from the fact that Turkey's ability to establish a "substantive democracy" is also essential for its ability to combine sustainable economic growth with a socially equitable pattern of development. Turkey's ability to overcome the middle-income trap is to a certain degree based on its ability to deepen a genuinely inclusive and pluralistic democratic order. The proposition that democracy and economic development in the Turkish context are parallel and interdependent processes are clearly highlighted by the fact that the deep-seated problems of the Turkish political 
economy — such as an exceptionally low female labor participation rate (around 28 per cent) which constitutes almost half of European Union average, major regional imbalances, and a comparatively high degree of income inequality (with a Gini coefficient of around 0.40 ) — can only be effectively resolved with the help of improved democratic governance. Moreover, progress in these spheres would have direct consequences for Turkey's foreign policy strategy, because Turkey needs to improve its democratic credentials and economic capacity to sustain and deepen its soft-power driven, pro-active regional power ambitions.

A comparative perspective suggests that Turkey constitutes an interesting case of a nearBRIC that tries to combine economic growth with a democratic form of government. Hence, at least in principle, it follows in the footsteps of the democratic variants of BRICs (such as Brazil and India) ${ }^{45}$ rather than of their authoritarian versions (such as China and Russia), even though Turkey continues to fall short of a consolidated liberal democracy. The important point to recognize, however, is that the changing global context may not necessarily create a favorable environment for democratic deepening in Turkey. Furthermore the European Union, which itself is in a deep economic and identity crisis has been losing its soft power over Turkey. Recent evidence indicates that, with the weakening of the formal Europeanization process associated with the European Union membership, a pronounced retrogression in democratization reforms has occurred. At a time when the European Union appeared to be less attractive as a model than before, the AKP leadership has been increasingly influenced by the more authoritarian versions of BRICs, given the outstanding economic performance of China, both in pre- and post- 
crisis contexts, and the growing strategic relationship with Russia, based on steadily expanding economic interactions over the past two decades. Indeed, Prime Minister Erdoğan has recently pronounced his desire for Turkey to leave its long-standing European Union aspirations and become a member of the Shanghai Cooperation Organization. ${ }^{46}$ Clearly, this marks a shift in Turkey's orientation, reflecting "conservative globalism" characterized by an eastern orientation, with emphasis on economic and political stability with a minimalist understanding of democracy, as opposed to the western focus of the early years of the AKP at the height of the EU-driven democratization reforms: This shift may have fundamental implications for the quality of Turkish democracy and reduce its value as a possible model combining elements of a successful economic transformation with strong democratic credentials.

\section{Turkey's shifting political economy landscape in the post-crisis era: Elements of a neo-developmentalist turn}

Having underlined the possible economic and political constraints on Turkey's regional power capacity, we identify certain changes that have gathered great momentum in the post-global crisis era. In the post-2001 period, Turkey developed a robust regulatory state compatible with the fundamental principles of the post-Washington Consensus. ${ }^{47}$ Accordingly, the Turkish financial system was placed under a strict surveillance framework via independent regulatory institutions, including the Banking Regulation and Supervision Agency. ${ }^{48}$ The regulatory policies pursued were quite effective, considering that Turkey is one of the rare countries that did not have to bail out its domestic banks during the $2007 / 8$ global financial crisis. ${ }^{49}$ The regulatory shift in the financial system, 
however, was not complemented by a pronounced industrial transformation strategy; as a result, Turkey has continued to pursue non-selective industrial policies in line with the dicta of orthodox liberalization. ${ }^{50}$

During the early phase of the AKP government the emphasis was on the regulatory rather than the developmental aspect of the state capacity. The transformations taking place in the post-crisis global political economy landscape, however, seem to have triggered a reshuffling in Turkish policy-makers' cognitive mindset as well. Turkey currently tries to formulate a pro-active industrial strategy, which embodies elements of a neodevelopmentalist turn. Prime Minister Erdoğan, clearly with an implicit agenda of matching and even emulating East Asia's developmental success, openly invited Turkey's top business groups "to produce domestic cars" in one of the meetings of the Turkish Industry and Business Association (TÜSİAD). The Turkish Minister of Science, Industry and Technology similarly shared his ambition to create "Turkey's own Renault, Fiat and Ford. ${ }^{, 51}$ The Turkish Prime Minister even set an overambitious target for Turkey’s industrial transformation strategy: "By 2023," declared Erdoğan, "we want Turkey to be one of the top ten economic areas of the world.... Over the next 15 years we want to increase the per capita income from $\$ 10,500$ to $\$ 25,000 .,{ }^{, 52}$

Not only the rhetoric, but also the policies implemented demonstrate that there are elements of a neo-developmentalist turn in Turkey's industrial policy. First, the Turkish Industrial Strategy Document: Towards EU Membership was adopted in 2011 under the auspices of the Ministry of Science, Industry, and Technology, along with the 
involvement of the relevant public and private bodies. ${ }^{53}$ The long-term goal of the industrial plan is set to position Turkey as "the production base of Eurasia in mediumand high-tech products.” In line with this overall objective, three basic strategic targets have been determined: (1) to increase the ratio of mid- and high-tech sectors in production and exports, (2) transition to high-value-added products in low-tech sectors, and (3) to increase the weight of companies that can continuously improve their skills. These industrial policy objectives are first and foremost designed to mitigate Turkey's proximate and structural challenges highlighted in the previous section.

The second aspect of Turkey's neo-developmentalist turn involves the implementation of investment stimulus packages. In 2012, the AKP government announced a new package to encourage investments that aims at reducing dependence on imported intermediate goods, thereby alleviating the current account deficit, improving the research and development (R\&D) base of the domestic economy, and mitigating regional imbalances within the country. The stimulus package, which divides Turkey into six regions, enables each one to receive different amounts of incentives, proportionate to regional socioeconomic inequalities, including corporate tax incentives, cuts in social security premiums, free land, and access to cheap credit. According to official figures, the incentive certificates issued total 32 billion US dollars in 2012 alone, comprising the most comprehensive amount of its kind in the country's economic history. ${ }^{54}$ The investment stimulus package, in fact, complements already-existing R\&D policies, whereby the AKP governments have poured considerable amounts of money into research and innovation over the last decade. Official figures indicate that R\&D 
expenditures tripled between 2002 and 2011, jumping from 3 to 9.6 billion US dollars. The full-time equivalent number of R\&D personnel increased from 28,964 to 92,801, and the number of researchers rose from 23,995 to $72,109 .{ }^{55}$ The industrial strategy document and the accompanying investment stimulus package are intended to build Turkey's R\&D capacity, by developing the necessary institutional framework and by allocating much needed financial sources.

The third aspect of Turkey's neo-developmentalist turn is related to the changing nature of state-business relations. The research suggests that state-business relations in Turkey have traditionally been overly fragmented, ideologically antagonized and conducted $a d$ hoc. ${ }^{56}$ Accordingly, institutionalized cooperation mechanisms between relevant state bureaucrats and business representatives remain rather weak. A relatively isolated, rather than insulated nature of the economic bureaucracy and a short-term-oriented, polarized relationship between economic interest groups and policy-makers characterize the main dynamics of state-business relations in Turkey. Furthermore, the relationship among different private economic interest groups is generally antagonized, because major business associations are organized along ideological lines. The recent state pro-activism toward capacity-enhancing reforms hints at certain structural changes in this realm as well. First, the institutional structure of the Turkish economy is being reorganized. The Ministry of Industry has been restructured and renamed the Ministry of Science, Industry and Technology, in order to make the role of "science" and "technology" more explicit for Turkey's industrial transformation strategy. Second, a separate state institutionnamely, the Ministry of Development - has been created in order to coordinate Turkey's 
economic development policies. Furthermore, the industrial strategy document acknowledges the importance of the "embedded autonomy" of the state, ${ }^{57}$ by underlining state-private business cooperation, as well as the internal coherence and synchronization of state bureaucracies:

To ensure the effectiveness of the industrial strategy, it is important to establish a high-level cooperation between the public and private sector... [Moreover] the cooperation and coordination among the public institutions is as important as the cooperation between the public and private sectors. ${ }^{58}$

To this end, deliberation councils that incorporate different stakeholders, such as representatives of employers and employees, are being established. Moreover, the relationships among private interest groups seem to undergo a gradual transformation. It is noteworthy in this context that the two leading business organizations-TÜSİAD, representing the pro-secular economic establishment, and the Independent Industrialists and Businessmen's Association (MÜSİAD), representing the conservative Anatolian bourgeoisie - which never before had come together, met twice after 2010. Moreover, TÜSİAD has recently veered towards a more inclusive approach to Anatolian capital. In TÜSİAD's $43^{\text {th }}$ General Assembly, Muharrem Yılmaz, known as one of the representatives of "Anatolian capital," was elected to become the organization's new president, along with four other representatives of the Anatolian bourgeoisie on the board of directors. ${ }^{59}$

These developments indicate that economic stakeholders in Turkey are aware of the "rise of global developmental liberalism" ${ }^{60}$ in the post-crisis political economy landscape. Similarly, the state invests in capacity-enhancing measures, not only in the regulatory, 
but also in the industrial realm. In short, these recent shifts signify a major response to deal with some of the major structural weaknesses and fragilities of the Turkish economy. It remains to be seen, however, whether the responses outlined will be sufficient in generating the kind of impact needed on the momentum of Turkey's long-term development performance.

\section{Conclusion: The potential and limits of "benign" regional power influence}

Opportunities have opened up for emerging powers to follow in the footsteps of the rising BRICs, as the world moves towards a new post-hegemonic age. In this novel international environment, the Turkish experience is illuminating for at least three major reasons. First, it displays how rising powers or near-BRICs are able to take greater advantage of the given conditions in order to pursue more pro-active and assertive regional agendas in the rapidly shifting global landscape. This paper has clearly illustrated both the potential and the limits of emerging power influence, with special reference to the Turkish experience.

Second, we have drawn attention to how the rise of BRICs itself has influenced the mindset of political elites in other emerging political economies. Political parties such as the AKP in Turkey are much more willing to pursue a pro-active foreign policy, with some degree of "autonomy thorough diversification," arm's length. They are also willing to use active state power to strengthen their domestic political powers, a development that is openly highlighted in our discussion of the neodevelopmentalist turn in Turkey, notably in the aftermath of the global economic crisis. 
Yet, our analysis also pointed to a kind of expectations-credibility gap. Middle powers in the emerging global context face the risk of over-estimating their leverage, especially in terms of unilateral action. The Turkish case constitutes a good illustration of this paradoxical tendency where over-confidence on the part of the architects of foreign policy has not been matched adequate power resources and the ability to influence actual outcomes.

The third implication of our paper concerns the future of liberal democracy. In the current global setting, liberal democracy is confronted with serious challenges in its heartlands, the United States and Western Europe, in the midst of a severe and continuing economic crisis. The rise of BRICs presents an uncertain future for liberal democracy, in the sense that some of the key BRIC countries have deeply rooted authoritarian regimes, which are unlikely to be dismantled in the short or medium term. In this context, countries such as Turkey are significant because they represent the democratic variant of BRICs or nearBRICs. The ability of such countries to combine economic success with liberal political values will be crucial for other countries following in their footsteps, particularly in their own neighborhood.

Our paper has finally demonstrated that, while combining economic success with democratic deepening is possible, the continued existence of this combination is by no means self-evident and faces formidable challenges. From a broader perspective, we should not discount the possibility that the rise of China and the economic success associated with the authoritarian version of the BRIC model may influence the mind-sets 
of political elites in near-BRIC countries like Turkey, with the obvious risk of side-

tracking democracy towards a more authoritarian direction, or at least in the direction of a

persistent regime of illiberal democracy. This tendency, as this paper argues, constitutes a major obstacle in terms of Turkey's ability to play the role of a benign regional power on a sustained basis. Turkey's claim to be a supporter of democracy and human rights in the Middle East is not likely to generate the desired response especially in the presence of major democratic deficits in the realm of its own domestic politics.

\section{Acknowledgements}

The earlier versions of this paper are presented at ISA Annual Convention, San Francisco, California, USA, April 3-6, 2013; Bilgi University, Workshop on the Political Economy of Turkish Foreign Policy, İstanbul, Turkey, 3 May, 2013; METU Conference on International Relations, Ankara, Turkey, 12-14 June, 2013. We would like to thank the participants of these events for their comments and critical insights.

\section{Notes}

\footnotetext{
${ }^{1}$ S. Walt, 'The end of the American era,' The National Interest, no. 116, 2011, pp 6-16; M Beckley, 'China's century: why America's edge will endure?' International Security, 36(3), 2011/12, pp 41-78; R Kagan, The World America Made, Knopf, 2012; C Kupchan, No One's World: The West, the Rising Rest, and the Coming Global Turn, Oxford: Oxford University Press, 2012.

${ }^{2}$ F Zakaria, The Post American World, New York: W.W. Norton \& Company, 2009.

${ }^{3}$ One may refer to comprehensive special issue of Third World Quarterly on the subject. For the editorial introduction of the special issue, see K Gray and C N Murphy, 'Introduction: Rising powers and the future of global governance', Third World Quarterly, 34(2), 2013, pp 183-193.

${ }^{4}$ We use the term "near-BRIC" for regional powers achieving high growth performance, demonstrating regional leadership ambitions, and following economy-driven autonomous foreign policy strategies. In the literature, there are alternative definitions attributed to these states, such as "middle powers," "swing states," "emerging powers," and "great peripheral states." In this study we call them "near-BRICs" in order to refer to the "demonstrative effects" of BRICs on these countries. In other words, these states possess characteristics similar to BRICs regarding their economic growth performance and rising regional and international presence; yet, they are not as significant as BRICs in terms of their economic scale.
} 
${ }^{5}$ N Ferguson, Civilization: The West and the Rest, London: The Penguin Press, 2011.
${ }^{6} \mathrm{P}$ J Katzenstein, $A$ World of Regions: Asia and Europe in the Age of American Imperium, Ithaca: Cornell University Press, 2005. For a critical review that puts great emphasis on the "endogenous construction of regions," see A Acharya, 'The emerging regional architecture of world politics,' World Politics, 59(4), 2007, pp 629-52.

${ }^{7}$ B Buzan and O Wæver, Regions and Powers: The Structure of International Security, Cambridge: Cambridge University Press, 2003.

${ }^{8}$ D Nolte, 'How to compare regional powers: Analytical concepts and research questions,' Review of International Studies, 36(4), 2010, pp 881-901.

${ }^{9}$ For the problem of generalization in case studies, see A L George and A Bennett, Case Studies and Theory Development in the Social Sciences, Cambridge: MIT Press, 2005.

${ }^{10} \mathrm{We}$ should state at the outset that in the present study we focus especially on two specific, yet constituting pillars of Turkey's regional power strategy—namely, economic dynamism and democratic deepening. We do not explicitly discuss other important dimensions of Turkey's soft power, mainly issues related to identity and civil society engagement.

${ }^{11}$ M Müftüler-Bac and F Keyman, 'The era of dominant party politics,' Journal of Democracy, 23(1), 2012, pp 85-99.

${ }^{12} \mathrm{Z}$ Öniş and Ş Y1lmaz, 'Between europeanization and euro-asianism: foreign policy activism in Turkey during the AKP era,' Turkish Studies, 10(1), 2009, pp 7-24.

13 'Suriye meselesi bizim iç meselemizdir,' http://www.akparti.org.tr/site/haberler/suriye-meselesi-bizimic-meselemizdir/11521, accessed 10 February 2013.

${ }^{14}$ M Akgün and S Gündoğar, The Perception of Turkey in the Middle East 2011, İstanbul: TESEV, 2012, p 12.

${ }^{15}$ For example, see C Tugal, 'Democratic janissaries: Turkey's role in the Arab Spring', New Left Review, 76, January-August 2012, pp 5-24.

${ }^{16} \mathrm{P}$ Bilgin, 'A return to 'civilizational geopolitics' in the Mediterranean? Changing geopolitical images of the European Union and Turkey in the post-cold war era,' Geopolitics, 9(2), 2004, pp 269-291.

${ }^{17}$ T Oğuzlu, 'Middle easternization of Turkey's foreign policy: does Turkey dissociate from the west?' Turkish Studies, 9(1), 2008, pp 3-20; F Keyman, 'Turkish foreign policy in the era of global turmoil,' SETA Policy Brief, no. 39, 2009.

${ }^{18}$ For the epistemological justification of analytic eclecticism, see P Katzenstein and R Sil, 'Eclectic theorizing in the study and practice of international relations,' in C Reus-Smit and D Snidal (eds.), The Oxford Handbook of International Relations, Oxford: Oxford University Press, 2008, pp 109-130.

${ }^{19} \mathrm{Z}$ Öniş, 'Turkey and the Arab spring: Between ethics and self-interest,' Insight Turkey, 14(3), 2012, p 52.

${ }^{20}$ For a framework of Turkey's economic penetration-democratization approach, see the speech of Turkish Minister of Foreign Affairs Ahmet Davutoğlu: 'Dışişleri Bakanı sayın Ahmet Davutoğlu'nun IV.

Büyükelçiler Konferansı açış konuşması,' http://www.mfa.gov.tr/disisleri-bakani-sn -ahmetdavutoglu_nun-iv_-buyukelciler-konferansi-acis-konusmasi_-23-aralik-2011.tr.mfa, accessed 22 February 2013.

${ }^{21}$ M Kutlay, 'Economy as the "practical hand" of new Turkish foreign policy: A political economy explanation,' Insight Turkey, 13(1), 2011, pp 67-89.

${ }^{22} \mathrm{~W}$ Hale and E Özbudun, Islamism, Democracy and Liberalism in Turkey: The Case of the AKP, New York: Routledge, 2010.

${ }^{23}$ I Bal, 'The PKK as the problem of Kurds,' Journal of Turkish Weekly, 14 October 2011; R Updegraff, 'The Kurdish question,' Journal of Democracy, 23(1), 2012, pp 119-128.

${ }^{24} \mathrm{~K}$ Kirisci, 'The transformation of Turkish foreign policy: the rise of the trading state,' New Perspectives on Turkey, no. 40, 2009, pp 29-57.

${ }^{25}$ Data have been retrieved from the Turkish Ministry of Economy and calculated by the authors.

${ }^{26} \mathrm{Z}$ Öniş, 'Turkey and the Arab spring: Between ethics and self-interest,' Insight Turkey, 14(3), 2012, pp 45-63.

${ }^{27}$ S Eken and S Schadler, Turkey 2000-2010: A Decade of Transition Discussions among Experts, Istanbul: DEIK Publications, 2012, p 36.

${ }^{28} \mathrm{G}$ A Calvo, A Izquierdo, and L Mejia, 'On the empirics of sudden stops: the relevance of balance-sheet effects,' NBER working paper series, no. 10520, 2004.

${ }^{29} \mathrm{~K}$ Boratav, Türkiye İktisat Tarihi, Ankara: İmge Kitabevi, 2012. 


\footnotetext{
${ }^{30}$ A Insel and F Kayıkc1, 'Evaluation of sustainability of current account deficits in Turkey,' Modern Economy, 3(1), 2012, pp 43-50.

31 'Energy dependence to grow in Turkey,' Hurriyet Daily News, 5 February 2013.

${ }^{32}$ The data have been retrieved from the Turkish Ministry of Economy.

${ }^{33}$ For recent research on the middle-income trap, see B Eichengreen, P Donghyung, and S Kwanho, 'When fast growing economies slow down: international evidence and implications for China,' Asian Economic Papers, 11(1), 2012, pp 42-87; B Eichengreen, P Donghyung, and S Kwanho, 'Growth slowdowns redux: New evidence on the middle-income trap,' NBER Working Paper, no. 18673, 2013.

${ }^{34}$ World Bank, China 2030: Building a Modern, Harmonious, and Creative High-Income Society, Washington, DC, 2012, p 13.

${ }^{35}$ For a comprehensive discussion of the phenomenon of the "middle income trap," with special reference
} to the Turkish case, see E Yeldan, K Taşc1, E Voyvoda, and M E Özsan, Orta Gelir Tuzağından Çıkış: Hangi Türkiye? Istanbul: TURKONFED, 2012.

${ }^{36}$ For comprehensive discussions of the issue, see D Rodrik, A Subramanian, and F Trebbi, 'Institutions rule: The primacy of institutions over geography and integration in economic development,' Journal of Economic Growth 9(2), 2004, pp 131-165.

${ }^{37}$ D Acemoğlu and J Robinson, Why Nations Fail, London: Profile Books, 2012, p 430.

${ }^{38}$ In terms of the quality of institutions, the performance of BRICs is not impressive at all. In fact, BRICs have their own domestic problems, which may constitute a stumbling block for their developmental performance in the coming years and decades. See R Sharma, 'Broken BRICs: Why the rest stopped rising,' Foreign Affairs, 91(6), 2012, pp 2-7.

${ }^{39}$ E Özbudun, 'Democratization reforms in Turkey, 1993-2004,' Turkish Studies, 8(2), 2007, pp 179-196.

${ }^{40} \mathrm{~J}$ Linz and A Stepan, Problems of Democratic Transition and Consolidation, Baltimore: Johns Hopkins University Press, 1996; A Przeworski, 'Democracy as a contingent outcome of conflicts,' in J Elster and R Slagstad (eds.), Constitutionalism and Democracy, Cambridge: Cambridge University Press, 1988, pp 5980.

${ }^{41}$ T Carothers, 'The end of the transition paradigm,' Journal of Democracy, 13(1), 2002, pp 5-21.

${ }^{42} \mathrm{M}$ Somer, 'Does it take democrats to democratize? Lessons from Islamic and secular elite values in Turkey,' Comparative Political Studies, 44(5), 2011, pp 511-545.

${ }^{43}$ The comparative analysis of the European Commission's annual progress reports on Turkey between 2007 and 2012 clearly documents this trend. Also see, Z Öniş, 'Sharing power: Turkey's democratization challenge in the age of the AKP hegemony,' Insight Turkey 15(2), 2013, pp 103-122.

${ }^{44}$ İ Turan, 'Encounters with the third kind: Turkey's new political forces are met by old politics', GMF Analysis on Turkey, June 26, 2013.

${ }^{45} \mathrm{O}$ Stuenkel, 'Rising powers and the future of democracy promotion: the case of Brazil and India', Third World Quarterly, 34(2), 2013, pp 339-355.

${ }^{46}$ E Berberoğlu, 'EU not a must for Turkey: PM Erdoğan,' Hurriyet Daily News, 6 February 2013.

${ }^{47} \mathrm{C}$ Bakır and Z Öniş, 'The regulatory state and Turkish banking reforms in the age of post-Washington consensus,' Development and Change 41(1), 2010, pp 77-106.

${ }^{48} \ddot{U}$ Sönmez, 'The political economy of market and regulatory reforms in Turkey: the logic and unintended consequences of ad-hoc strategies,' New Political Economy 16(1), 2011, pp 101-130.

${ }^{49} \mathrm{Z}$ Öniş and A B Güven, 'Global crisis, national responses: the political economy of Turkish exceptionalism,' New Political Economy 16 (5), 2011, pp 585-608.

${ }^{50}$ E Taymaz and E Voyvoda, 'Marching to the beat of a late drummer: Turkey's experience of neoliberal industrialization since 1980,' New Perspectives on Turkey, no. 47, 2012, pp 83-113; M Kutlay, 'Internationalization of finance capital in Spain and Turkey: Neoliberal globalization and the political economy of state policies,' New Perspectives on Turkey, no. 47, 2012, pp 115-137.

${ }^{51}$ G. Benmayor, 'Turkey's dream of a domestic car,' Hurriyet Daily News, 5 February 2013.

${ }^{52} \mathrm{R}$ T Erdoğan, "Turkish economy meets EU entry criteria," http://www.huffingtonpost.com/recep-tayyiperdogan/the-turkish-economy-meets b 2205265.html, 28 November 2012.

${ }^{53}$ Republic of Turkey Ministry of Industry and Trade, 'Turkish industrial strategy document: Towards EU membership (2011-2014),' http://www.sanayi.gov.tr/Files/Documents/TurkiyeSanayiStratejisiIngilizce.pdf ${ }^{54}$ The data have been retrieved from the Ministry of Economy.

${ }^{55}$ The data have been retrieved from the Prime Ministry, Undersecretariat of the Treasury. 
${ }^{56}$ M Heper (ed.), Strong State and Economic Interest Groups: The Post-1980 Turkish Experience, Berlin: Walter de Gruyter, 1991; A Buğra, Devlet ve İşadamları, İstanbul: İletişim Yayınları, 2005.

${ }^{57}$ For the concept of "embedded autonomy," see P Evans, Embedded Autonomy: State and Industrial Transformation, Princeton: Princeton University Press, 1995.

${ }^{58}$ Turkish industrial strategy document: Towards EU membership (2011-2014), p 134.

${ }^{59}$ See TÜSİAD's official website, www.tusiad.org.

${ }^{60} \mathrm{P}$ Cammack, 'The G20, the crisis, and the rise of developmental liberalism,' Third World Quarterly, 33(1), 2012, pp 1-16.

${ }^{61}$ For the logic of "autonomy through diversification," especially in the Brazilian case, see T Vigevani and G Cepaluni, 'Lula's foreign policy and the quest for autonomy through diversification,' Third World Quarterly, 28(7), 2007, pp 1309-1326.

\section{Notes on Contributors}

Ziya Öniş, Koç University, Department of International Relations and Political Science, İstanbul, Turkey. His recent research areas include democratization, political economy of emerging powers, Turkish foreign policy in comparative perspective. His publications appeared in Third World Quarterly, New Political Economy, Review of International Political Economy, Development and Change, Mediterranean Politics, Turkish Studies, and Insight Turkey.

Mustafa Kutlay, Koç University, Department of International Relations and Political Science, İstanbul, Turkey. His main research areas include comparative political economy, political economy and foreign policy of Turkey, Greece, and Turkey-EU relations. His articles appeared in Third World Quarterly, Perspectives on European Politics and Society, New Perspectives on Turkey, Insight Turkey, Perceptions, and Uluslararası İlişkiler. 